
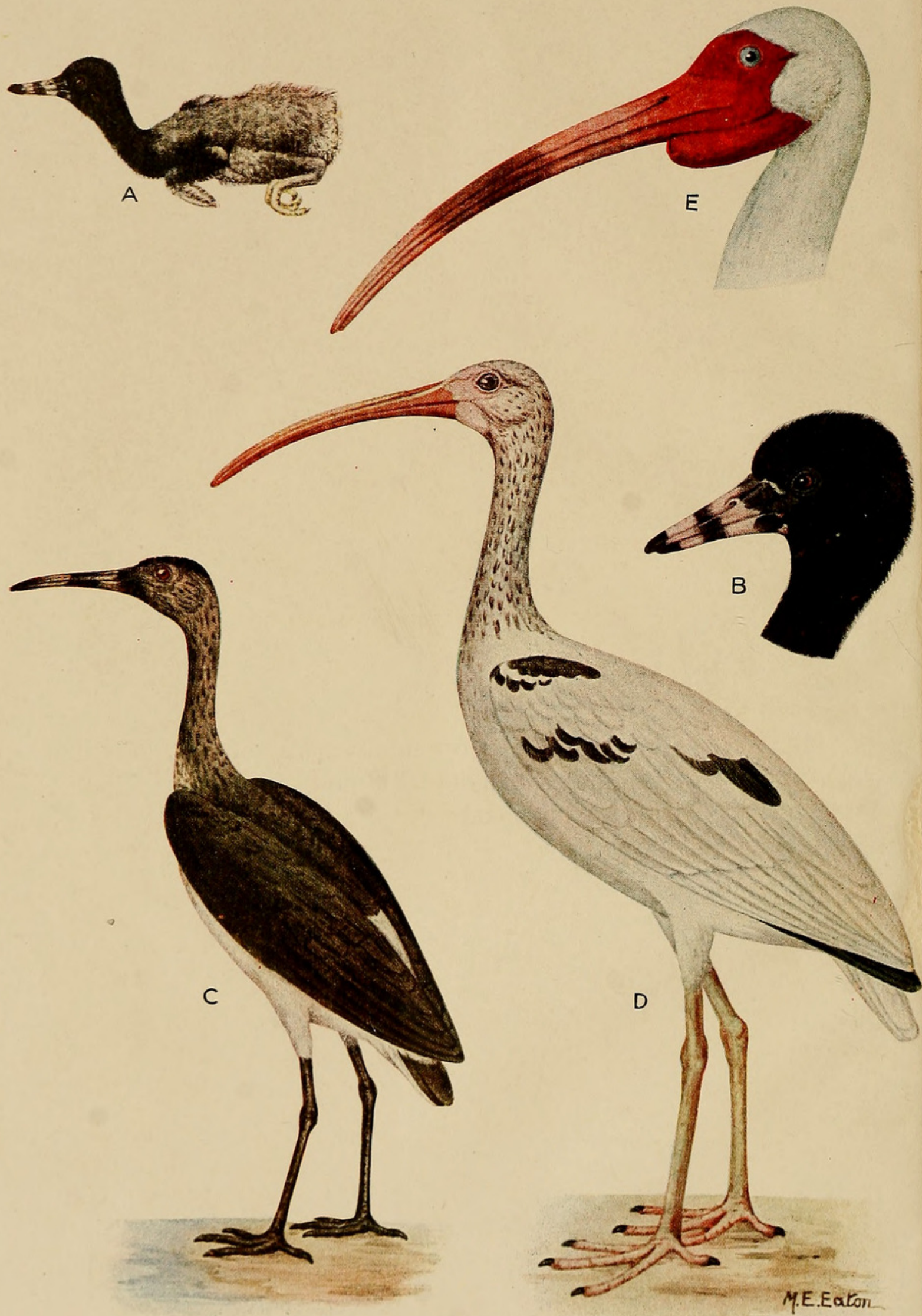

Fig. 97. PLUMAGES OF THE WHITE IBIS.

A, Downy Chick; B, Head of downy chick; C, Juvenile plumage: D, Post-juvenile plumage:

$\mathrm{E}$, Head of adult male in the breeding season. 


\title{
NOTES ON THE ONTOGENY OF THE
}

\section{WHITE IBIS, GUARA ALBA}

\author{
By C. William BeeBe, Curator of Birds.
}

Part I-Breeding Habits.

As soon as the White Ibises are placed outdoors in the large flying cage, in the spring of the year, the breeding pairs spend much of their time in the small tree in which they have nested for the past two seasons. Usually one of the two nests has survived the winter's storms and shows at least a solid basal platform of twigs. There seems to be little definite courtship in these captive birds, and I am quite certain that they remain paired throughout the year. There is much quarreling over the nests, but as for two seasons in succession the same sites have been chosen, there is little doubt that each pair occupies the same nest or nesting site.

At first the males remain in the vicinity of the tree more than the females, and indeed, for many days before actual building commences the males will spend almost the entire day, standing on the old nest or a nearby branch, one leg drawn up, but watchful and ready with raised wings, open beak and inflated chin pouch to frighten away any other birds intruding on their territory.

The sexes share equally in bringing material for the nest, although the actual interlacing of twigs seems to be the duty of the female. At least I have seldom seen the male do more than awkwardly fiddle about with a twig which he had brought, while upon the arrival of his mate he stepped out upon a branch and allowed her to attend to the actual building.

I have never known when the first egg was deposited and not until the full set is laid is there any abstract hint of eggs in the nest, and this only from the continual setting of the birds. Both take part in incubation, and during different times in the day I have seen the male as often as the female on the eggs. It is not uncommon for the male to bring fish to his mate, but I 
have not observed a reverse case of feeding. The eggs are laid in June, usually about the first week, and the time of incubation lies between twenty and twenty-three days. Both parents take part in feeding the young. The comminuted fish is brought in the gular sac which is developed in both sexes. The male, owing to the enlargement of the chin sac, is able to pack much more into his throat than his mate. When one of the old birds comes to the nest with food, the bill is opened widely and the young Ibis reaches up and takes the food from the throat of the parent. The sight of this feeding process is contagious and I have seen unmated ibises moved to fly up with offerings of food, and even the young bird of the preceding year makes similar attempts. All are hustled away by the parents, however, before they have had even a chance to carry out their altruistic efforts.

\section{Development and Annual Changes.}

For several years one or two pairs of White Ibis, Guara alba (Linnæus), have bred in the flying cage of the New York 7oological Park. Usually two eggs are deposited but only a single bird in each brood is reared to maturity. In 1912, a young Ibis was hatched on July 6th, and another in a second nest, about a month later. The desire to have this species established as a regular annual breeder in the Park has led me to leave the birds almost wholly undisturbed, but it was found possible during the present year to make a number of new observations, and the necessary handling of the nestling did not interfere with the faithful care of the parents, who were able successfully to rear the young bird.

No definite description of the sequence of plumages in the White Ibis has ever been written, as far as I have been able to discover, and knowledge of the time of attainment of the fully adult plumage is equally vague. In many ways Audubon's account is not reliable.

The nestling in down plumage reveals a number of interesting characters. At the time of hatching, the pterylosis of the bird shows a very advanced development of down on the anterior portions. Thus the head, neck, upper breast and anti- 
brachium or fore-arm are covered with a dense growth of down, jet black on the crown where it is sleek and velvety, but becoming somewhat longer and of a brownish, smoky hue on the neck and wings. The remainder of the body is at first almost bare and later only thinly clad with straggling, woolly down, smoky gray on the dorsal surface and white on the under parts. It would seem as if the young bird was prepared for protection from the cold only on the head and neck, somewhat as in the emperor penguin, in which these portions project from the dermal pouch of the parents.

The crown down consists of a spray of 10 or 12 spine-like barbs, of equal length (about $6 \mathrm{~mm}$.), furnished with simple barbules along their basal half. A down feather from the back has usually a greater number of barbs, considerably longer (15 mm.), whitish at the base, shading into smoky gray, very soft and pliable and clothed almost to the tip with barbules of similar texture. These two types of down characterize the two distinct zones which I have mentioned. The egg-tooth is small but very sharp, white and fixed on a dusky rectangular base which is shed about the third day. The wing claws are small, with sharp, recurved tips and are present on the first and second digits. The legs and feet are large and strong. All the visible skin of the body and the anterior aspect of the tarsus is of a dull leaden hue, the posterior tarsus and the feet being flesh colored. The curious changes in the flesh colors of the face and bill and the iris I will describe separately.

Although at the time of hatching the down of the head and neck is more advanced than that of the body in general, yet the changes which take place during the ensuing two or three weeks reverse this condition. The contour feathers of the body and wings sprout at once while the head and neck remain as at birth. During the third week when the sheaths have begun to dry up and the juvenile plumage becomes recognizable, the young bird becomes restless and now and then climbs out of the nest and along the nearby branches. When a month old, if frightened it will fall or scramble to the ground, but when this happens in the flying cage the young Ibis is not able to return in spite of its excellent climbing powers, but must be replaced by the keeper. 
In the southern White Ibis rookeries, scores of young birds at this stage are to be seen scampering about in flocks on the ground, long before they can fly.

About the sixth week the young bird begins to use its wings and in a few days can accompany its parents in search of food during the day, returning with them to roost on or near the nest at night. Even at this time there is little change in the nestling plumage of the neck, but when the flight feathers have reached their full development, most of the neck down has been shed. The last trace of this nestling down is found on the crown, where it remains as a conspicuous spot of dense velvety black, many days after the bird is in full juvenile dress. This mark may be distinguished a long distance off.

In this juvenile plumage the head and neck are streaked. The feathers are gray or ashy white with darker brown centers. This dark marking is most pronounced on the head and upper neck, narrowing and paling on the throat and lower neck, and dying out in the form of shaft streaks on the breast. The ventral plumage from the breast backward, the lower back, sides, rump, tail-coverts, the basal half of the tail and the under surface of the wings are pure white. The entire wing, mantle, scapulars and terminal half of the tail are olive brown, most of the feathers with an oily green gloss, changing to copper. The concealed portion of nearly all these feathers is more or less white.

We thus see that except for the smoky gray down of the upper part of the body being replaced with white, the general arrangement of color in the nestling and in the juvenile plumage is similar.

Except for a steady increase in size and the gradual loss of the velvety down cap, no further change takes place during the first summer and autumn, but late in the winter, usually about February, a moult begins, starting on the mantle and scapulars, and spreading outward over the wings and posteriorly to the tail. This mouit is not a short, well defined one but proceeds slowly throughout the year both in wild and in captive birds. In the second summer, the bird is usually quite white, retaining only the old primary and tail-feathers and those of 
the head and neck. These become exceedingly worn, frayed and faded to a sandy brown. The two former are shed at the regular season for moulting of the species, but not until October or November of the second year is the plumage of the head and neck renewed, that of the crown persisting, as before, until all the other feathers are shed. In the spring the gular pouch begins to be developed in the males and the scarlet breeding pigment appears, and the bird is ready to breed in fully adult plumage in the third summer of its life, when two years old.

The changes in the White Ibis, in the color and pattern of the fleshy parts, eyes and bill during growth are of interest. In the downy chick the irides are hazel, the bill short and straight. The most common type of bill coloring during the first week of life is where it is crossed by five zones of color, two median bands of pinkish flesh, bounded by three equally broad areas of black, the most distal at the very tip of the beak, the second across the center and the third occupying the entire basal area, except for a narrow white frontal line in front of the eyes and extending longitudinally along the margin of the feathered area. There are also two small gular patches of pink and the skin of the chin, between the mandibles, is of the same color. The culmen of the three-day chick measures about 19 mm., the lower mandible being several millimetres shorter. This inequality in length, curiously enough, is reflected in the terminal band of pigment, which extends considerably farther toward the base than the corresponding dark area on the tip of the upper mandible.

A good deal of variation is observable in a series of chicks but the five-banded beak is characteristic. The next commonest type is where all but the distal band of black is absent.

In the chicks hatched in captivity the white loral spots disappear before the end of the second week. This transient character is of interest as perhaps representing the permanent facial marking of the related Glossy Ibis (Plegadis autumnalis).

On the sixteenth day, July 29th, the increase in the length of the bill was about 12 per cent. On the thirty-fifth day the basal part of the bill had become entirely black, with the exception of the distal band of pink which persisted conspicuously. 
The two gular patches had increased in size and intensity of color.

On the fifty-sixth day the pale band had disappeared from the lower mandible, but was still discernable on the upper. A new area of pale color had now appeared at the tip of the upper mandible.

About a month later, when the young bird was eighty-three days old, the pale terminal area on both mandibles had spread backward, so that the anterior half of the beak was then a clouded pinkish. The basal half was not as black as in the young chick. Ten days later the pinkish area had reached the second of the congenital pale zones, and the skin around the eye had become distinctly pink.

In the six months' old bird the bill was wholly of a clouded pink color, very much lighter than in the adults. The bare face was pale flesh color. The iris at this age was pale slate blue, with a narrow inner ring of hazel.

Recorded measurements in millimetres are as follows:

Length. Culmen. Wing. Tail. Tarsus.

3-day chick

150

19

29

23-day chick

230

37

2-months' juvenile

450

18-months' bird

625

65

Fully adult bird

675

158

60

235

286

168

290

22

55

75

92

I have kept a record of the pigment producing possibilities of the feathers of a young growing White Ibis. The feathers of the juvenile tail are uniform only in that the terminal half is brown, and the basal half white. The zone of darker color is not constant, and in the twelve feathers of any individual no two may be alike, while the white area may be immaculate, or variously clouded or mottled, especially on the outer web, with brown pigment. A feather may appear, which on the terminal half, is solid brown on the inner, broader web, while the outer is pure white, the line of demarcation here being the shaft, but this is exceptional. Having in mind that it is upon such variations in feathers that the theory of color-change in the dead feather has been chiefly based, I applied the only possible proof, and by marking feathers such as the last, kent them under con- 
tinual observation. The appearance of such asymmetrically pigmented feathers would seem to lend credence to such colorchange, but in every case where my clipped and threaded observation feathers were scrutinized, there was no infiltration or even local wearing or change in area of pigmentation whatsoever. The variation in the juvenile feathers of the White Ibis is congenital, not transitory or ontogenetic.

If feathers be plucked out from the wings of a two months' old bird, the new growths which take their place differ little or not at all from the original ones. In the third and fourth months, however, much of the immature brown pigment is lost, and from the sixth month onward the ingrowing feathers will be pure white as in the adult. Normally these would not appear for another six or eight months. In the five months' old bird one can readily detect every vicious peck it has received from other inmates of the cage, by the white feather or group of feathers which marks the place of the others plucked out.

In early spring, if one of the dull brownish outer primaries be pulled out, there comes in a feather, not pure white, but with the pigment strengthened and concentrated on the terminal half and very strongly glossed with iridescent green. This is identical with what I found occurring in the intensified melanism zones in wild doves. ${ }^{1}$

Nothing definite seems to have been recorded in regard to the annual change in color of the exposed soft parts of the adult White Ibis. In mid-winter, the bill and face of the bird is of a rich fleshy pink, evenly colored throughout. About Christmas or the first of the year the first change is noticeable, which, rather remarkably, is a paling of the color. The region about the eye, the lores and the base of the bill for some $15 \mathrm{~mm}$. from the base, fades from pink, to pale pinkish white. The face and the basal band on the bill, about mid-February, again increases in color and gradually becomes intensified. The legs and feet show no change but the cheeks, with their white feathering, begin to be puffed out. A month later, well into March, the most interesting change is a dark ring which appears around the middle of the beak about $75 \mathrm{~mm}$. from the tip and spreads in both

1 Zoologica, Vol. I. No. 1, p. 31. 
directions. This darkens and clouds the pink but does not wholly obscure it. The legs now begin to brighten.

In April the face and basal portion of the beak are scarlet, and the chin swelling very large. The black, in some individuals, reaches the tip of the beak, in others remains as a very wide band, occupying the middle third of the mandibles. The first of June sees the height of nuptial development (Fig. 97, E). The pure white birds show face and mandibles, legs and feet of richest scarlet, the bill paling anteriorly and tipped or banded with dusky. The cheeks protrude, the bluish white eyes stand out in strong contrast against the surrounding scarlet. The skin of the chin is produced into an inflatable sac which at moments of intense excitement protrudes like a rounded scarlet bladder. After the eggs are laid, the coloring diminishes and the chin pouch becomes reduced about half, or at least is seldom swelled out to full size. The paling of the red in the mandible throws the dark area into stronger contrast for a time, when it too loses strength and fades. The females are less brilliant and almost lack the chin swelling.

For the notes on changes in the color of the beak of the young Ibis I am indebted to Mr. Crandall, and for the loan of skins to Dr. Dwight and Mr. Chapman. 


\section{$2 \mathrm{BHL}$ Biodiversity Heritage Library}

Beebe, William. 1914. "Notes on the ontogeny of the white ibis, Guara alba." Zoologica : scientific contributions of the New York Zoological Society 1(12), 241-248. https://doi.org/10.5962/p.206596.

View This Item Online: https://www.biodiversitylibrary.org/item/97326

DOI: https://doi.org/10.5962/p.206596

Permalink: https://www.biodiversitylibrary.org/partpdf/206596

\section{Holding Institution}

Harvard University, Museum of Comparative Zoology, Ernst Mayr Library

\section{Sponsored by}

Harvard University, Museum of Comparative Zoology, Ernst Mayr Library

\section{Copyright \& Reuse}

Copyright Status: Public domain. The BHL considers that this work is no longer under copyright protection.

This document was created from content at the Biodiversity Heritage Library, the world's largest open access digital library for biodiversity literature and archives. Visit BHL at https://www.biodiversitylibrary.org. 